\title{
TANGGUNG JAWAB PEMDA TERHADAP KERUSAKAN LINGKUNGAN HIDUP KAITANNYA DENGAN KEWENANGAN PERIZINAN DI BIDANG KEHUTANAN DAN PERTAMBANGAN ${ }^{\Omega}$
}

\author{
Marhaeni Ria Siombo \\ Fakultas Hukum Universitas Katolik Indonesia Atmajaya \\ E-mail: riasiombo@yahoo.com
}

\begin{abstract}
Indonesia government has been struggling for implementing the concept of sustainable development nationwide. The Act No. 32 of 2004 on Regional Government gives the authority to local government widely, particularly relate to license of natural resources exploration in forestry and mining. Local Government has a strategic role with the given authority to issue IUP Exploration and IUP Production Operation, for mining businesses. Mining activities are very susceptible to environmental damage. Therefore, the authority given to local governments should be implemented with full responsibility. Moreover, they should realize that their role as local governments is essential in maintaining environmental quality in the region. At this point, in many cases, many local government officials have chances to violate their authority. Consequently, corruption is not inevitable. Ultimately environmental considerations are not a priority or primary consideration. The environmental damage that occurred in the region is the responsibility of local government, as part of the given authority.
\end{abstract}

Key words : environmental damage, the mining licensing authority (IUP), the responsibility of local governments.

\begin{abstract}
Abstrak
Pemerintah RI sampai saat ini terus berusaha untuk menerapkan konsep 'sustainable development' dalam melaksanakan pembangunan di wilayah RI. UU No.32 Tahun 2004 Tentang Pemerintahan Daerah, memberikan kewenangan kepada daerah yang sangat luas, terutama berkaitan dengan perizinan dalam pemanfaatan sumberdaya alam bidang kehutanan dan pertambangan. Pemerintah Daerah memiliki peran yang startegis dengan diberikannya kewenangan menerbitkan IUP Eksplorasi dan IUP Operasi Produksi bagi perusahaan pertambangan. Aktivitas pertambangan sangat rentan terhadap terjadinya kerusakan lingkungan. Oleh karena itu kewenangan yang diberikan pemerintah kepada pemerintah daerah harus dilaksanakan dengan penuh tanggung jawab dan kesadaran bahwa peran pemerintah daerah sangat penting dalam menjaga dan mempertahankan kualitas lingkungan di wilayahnya. Pada titik inilah, dalam banyak kasus, banyak pejabat pemerintah daerah kabupaten/kota bermain mata sehingga praktek korupsi tidak terhindarkan, yang pada akhirnya pertimbangan lingkungan tidak menjadi prioritas atau pertimbangan utama. Kerusakan lingkungan yang terjadi di daerah, merupakan tanggung jawab pemerintah daerah, sebagai bagian dari paket kewenangan yang diberikan.
\end{abstract}

Kata kunci : kerusakan lingkungan, kewenangan perizinan pertambangan (IUP), tanggung jawab pemerintah daerah.

Pendahuluan

Pertimbangan diterbitkannya UU No. 32 Tahun 2009 tentang Perlindungan dan Pengelo-

$\Omega \quad$ Artikel ini merupakan artikel hasil penelitian dengan sumber dana dari Pengembangan Penelitian FH UNIKA ATMA JAYA 2014 yang dilaksanakan berdasarkan Surat Tugas Penelitian dari Dekan Fakultas Hukum UNIKA ATMA JAYA Nomor 1200/III/FH.D/KP.104.01/01/2014. laan Lingkungan Hidup (PPLH), menyatakan bahwa pembangunan ekonomi nasional sebagaimana diamanatkan oleh Undang-Undang Dasar Negara Republik Indonesia Tahun 1945 (yang selanjutnya disingkat UUD 1945) diselenggarakan berdasarkan prinsip pembangunan berkelanjutan dan berwawasan lingkungan. Pertimbangan ke- 
dua menyatakan bahwa semangat otonomi daerah dalam penyelenggaraan pemerintahan Negara Kesatuan Republik Indonesia telah membawa perubahan hubungan dan kewenangan antara Pemerintah dan pemerintah daerah, termasuk di bidang perlindungan dan pengelolaan lingkungan hidup. Pertimbangan ketiga menyatakan bahwa kualitas lingkungan hidup yang semakin menurun telah mengancam kelangsungan perikehidupan manusia dan makhluk hidup lainnya sehingga perlu dilakukan perlindungan dan pengelolaan lingkungan hidup yang sungguh-sungguh dan konsisten oleh semua pemangku kepentingan.

Pembangunan dan prinsip-prinsip kelestarian alam pada masa lalu dipandang sebagai dua kutub yang berlawanan yang tidak bisa bertemu. Kesadaran masyarakat dunia melalui konferensi lingkungan hidup tentang pentingnya pembangunan dan sangat pentingnya menjaga kelestarian alam, membuka mata pemimpin dunia untuk menemukan konsep pembangunan dengan tetap memperhatikan prinsip kelestarian alam. Adanya konsep 'pembangunan yang berkelanjutan' yang memadukan aspek ekologis, sosial dan ekonomi dalam suatu strategi pembangunan merupakan formula yang sampai saat ini digunakan oleh semua negara di dunia, termasuk Indonesia. Pemanfaatan sumber daya alam (yang selanjutnya disingkat SDA) dilandasi oleh tiga pilar pembangunan berkelanjutan, yaitu menguntungkan secara ekonomi (economically viable), diterima secara sosial (socially acceptable), dan ramah lingkungan (environmentally sound). Proses pem bangunan yang diselenggarakan dengan cara tersebut diharapkan dapat meningkatkan kesejahteraan dan kualitas kehidupan generasi masa kini dan yang akan datang.

Indonesia memiliki banyak SDA yang harus dibangun artinya pembangunan harus dilakukan, karena pembangunan merupakan jembatan menuju kesejahteraan masyarakat, sebagaimana di amanatkan dalam Pasal 33 UUD 1945, bahwa bu$\mathrm{mi}$, air dan kekayaan alam yang terkandung di dalamnya yang menguasai hayat hidup orang banyak dikuasai oleh negara, untuk dipergunakan sebanyak-banyaknya bagi kesejahteraan dan kemakmuran masyarakat Indonesia. Pembangunan haruslah mampu untuk menjaga keutuhan fungsi dan tatanan lingkungan, sehingga SDA yang ada dapat senantiasa tersedia guna mendukung kegiatan pembangu-nan baik untuk masa sekarang maupun masa yang akan datang. Pengaturan hak-hak dasar masyarakat dalam UUD 1945 dapat dikategorikan menjadi 3 (tiga) yaitu norma dasar hak masyarakat secara individu, norma dasar hak masyarakat secara kolektif, dan norma dasar hak bagi anak. ${ }^{1}$ Penguasaan negara terhadap bumi, air dan kekayaan alam yang terkandung di dalamnya, untuk kesejahteraan dan untuk memenuhi hak-hak dasar masyarakat secara individu maupun secara kolektif.

Namun demikian pemanfaatan SDA terutama di bidang kehutanan dan pertambangan harus dimanfaatkan dan dikelola berdasarkan prinsip yang ada dalam konsep pembangunan berkelanjutan, bahwa keseimbangan ekosistem dioptimalkan untuk tetap terjaga, dengan me'manage' dampak sehingga dampak lingkungan dapat diminimalkan. Pemerintah sebagai penyelenggara negara yang diberi kewenangan mengatur tata kelola pemerintahan telah mengeluarkan regulasi yang berkaitan dengan pemanfaatan SDA, bagaimana memanfaatkan SDA bidang kehutanan dan pertambangan dan bagaimana mengelola dampak lingkungan. UU No. 4 Tahun 2009 tentang Pertambangan Mineral dan Batubara, salah satu diantaranya dan UU No. 32 tahun 2009 tentang Perlindungan dan Pengelolaan Lingkungan Hidup merupakan pedoman umum yang khusus mengatur bagaimana melakukan pengelolaan lingkungan hidup sekaligus memberikan batasan-batasan dan persyaratan yang bersifat preventif dan represif. Selanjutnya sebagai pedoman khususnya adalah Peraturan Pemerintah No. 27 Tahun 2012 tentang Izin Lingkungan yang merupakan pelaksanaan dari Pasal 33 dan pasal 41 UU No. 32 Tahun 2009. Batasan-batasan yang bersifat preventif (administrasi) ini merupakan implementasi pelaksanaan tiga pilar pem- 
bangunan berkelanjutan sebagaimana disebutkan di atas.

UU No. 4 Tahun 2009 yang mengatur tentang usaha pertambangan diterbitkan diera otonomi daerah dengan adanya UU No. 32 Tahun 2004, dimana daerah diberikan kewenangan untuk mengatur dan mengurus wilayahnya, mengelola SDA di wilayahnya, termasuk di bidang perizinan. Penerbitan Izin Usaha Pertambangan (yang selanjutnya disingkat IUP) dilimpahkan kepada pemerintah daerah, sebagai wujud pelaksanaan otonomi daerah.

Di sinilah mulai sumber permasalahan terjadi. Pemerintah daerah yang diberi kewenangan mengeluarkan perizinan dalam hal ini Izin Usaha Pertambangan (IUP), terkesan longgar dalam menerapkan prosedur yang seharusnya dilaksanakan sebelum diterbitkannya IUP. Sebelum diterbitkan IUP harus terlebih dahulu melewati tahapan 'izin lingkungan' yaitu izin yang diberikan kepada setiap orang yang melakukan Usaha dan/atau kegiatan yang wajib Amdal atau UKL-UPL dalam rangka perlindungan dan pengelolaan lingkungan hidup sebagai prasyarat memperoleh izin Usaha dan/atau kegiatan. Persyaratan administrasi ini merupakan alat kontrol (pemantauan dan evaluasi) pemerintah daerah, agar tidak terjadi kerusakan lingkungan di wilayahnya.

Kenyataan yang terjadi saat ini adalah sebaliknya, pemberian IUP menjadi obyek 'praktek korupsi' oknum penguasa di daerah. Hasil penelusuran Jaringan Advokasi Tambang (JATAM) Sulawesi Tengah, menyatakan bahwa "Dugaan Korupsi di sektor sumber daya alam di Sulawesi Tengah begitu masif, ditandai dengan adanya peningkatan Izin Usaha Pertambangan setiap tahunnya, atau setiap pergantian Kepala Daerah". Dalam pernyataannya JATAM mendukung Komisi Pemberantasan Korupsi (KPK) untuk mengusut tuntas kasus-kasus dugaan korupsi di sektor SDA, khususnya di bidang pertambangan di Sulawesi Tengah. ${ }^{2}$ Hasil temuan Badan Pemeriksa Keuang-

2 Rifai Hadi, Manager Riset JATAM SULTENG, “Penyalahgunaan IUP dan Kerusakan Lingkungan", suaraagraria. com, 2013.

3 Busro Muqodas, "IUP Bermasalah", Hukumonline.com, 10 Pebruari 2014. an (BPK) menyimpulkan pasca bergulirnya kebijakan otonomi daerah (Otda) sejalan reformasi di Indonesia, berdampak terhadap kerusakan lingkungan dan meningkatnya korupsi dan adanya fakta bahwa hingga kini sudah 311 kepala daerah telah berurusan dengan penegak hukum terkait korupsi, yang antara lain dikarenakan terjadinya penyalahgunaan kewenangan missalnya soal izin konsesi hutan termasuk soal IUP. Bahkan Komisi Pemberantasan Korupsi (KPK) menemukan, dari 7.501 izin usaha pertambangan ternyata 45 persen di antaranya bermasalah. ${ }^{3}$ Jika demikian maka Izin Lingkungan sebagai persyaratan administrasi yang harus dipenuhi, menjadi formalitas belaka tanpa makna, yang pada akhirnya mengakibatkan kerusakan lingkungan terus terjadi tak terkendali. Pada hal persyaratan yang harus dipenuhi untuk mendapatkan IUP sudah dibuat sedemikian rupa begitu ketat tetapi karena kewenangan pemerintah daerah yang terlalu luas, tanpa memperhatikan ketidaksiapan aparatur didaerah dalam menghadapi praktek-praktek korupsi yang begitu mudahnya mendapatkan IUP.

UU N0. 32 tahun 2009 di buat diera reformasi. Fokus dalam reformasi adalah pembentukan dan pembinaan good governance, good dalam fungsinya menuntut konsistensi, transparansi, kredibilitas, akuntabilitas, dan prediktabilitas dalam penyelenggaraan pemerintahan di bidang politik, ekonomi dan hukum. ${ }^{4}$

\section{Metode Penelitian}

Terhadap kerusakan lingkungan akibat kegiatan pertambangan penulis beberapa kali kunjungan ke beberapa wilayah melewati, melihat dan mengamati langsung (observasi) kerusakan lingkungan yang terjadi karena aktivitas pertambangan. Berdasarkan hasil pengamatan tersebut, mendorong penulis menelusuri per-aturan perundanga-undangan terkait, sebagai sumber data primer peraturan perundangan yang berkaitan dengan lingkungan hidup, pertambangan, 
otonomi daerah serta sumber data lainnya dari bahan hukum terutama hasil penelitian yang mengangkat tentang otonomi daerah dan izin usaha pertambangan, dan didukung oleh data sekunder lainnya, yang dalam penelitian hukum dikategorikan sebagai penelitian normatif yang sifatnya deduktif.

\section{Pembahasan}

\section{Pembangunan Berkelanjutan}

KTT di Rio de Janeiro 1992 mendeklarasikan 5 (lima) prinsip sustainable development, sebagai berikut. Pertama, Intergenerational Equity (Prinsip Keadilan Antar-Generasi) Prinsip ini memandang bahwa setiap generasi berperan sebagai trustee dari ekosistem atau SDA supaya dapat bermanfaat bagi generasi berikutnya dan sekaligus sebagai penerima manfaat dari generasi sebelumnya; kedua, Intragenerational Equity (Prinsip Keadilan Intra-Generasi); ketiga, Precautionary principle (Prinsip Pencegahan Dini) Upaya untuk melakukan pencegahan atas aktivitas yang mungkin akan menyebabkan kerusakan lingkungan. Tidak ada alasan apapun untuk menunda upaya mencegah terjadinya suatu kerusakan lingkungan. Masyarakat dunia menyadari bahwa ancaman kerusakan lingkungan sangat serius dan bersifat irreversible (tidak dapat dipulihkan), misalnya pengolahan SDA pertambangan, yang mengancam kehidupan manusia, karena akan ada keadaan di mana tidak dapat disubtitusi dari sumber daya yang digunakan; keempat, Conservation of Biological Diversity (Perlindungan keanekaragaman Hayati); Keanekaragaman hayati perlu dipertahankan karena merupakan sumber kehidupan manusia yang berkaitan dengan pangan, obat-obatan, dan kesu-buran tanah; dan kelima, Internalization of Environmental Coast and incentive Mechanism (Internalisasi biaya lingkungan dan mekanisme insentif).

Biaya lingkungan dan sosial harus diintegrasikan ke dalam proses pengambilan keputusan yang berkaitan dengan penggunaan sumber-sumber alam, yang meliputi pengaturan tentang charge, fees perizinan dll. Hal ini dilakukan karena

Mas Achmad Sentosa, 2014, "Gerakan Pembaharuan Hukum Lingkungan di Indonesia \& Perwujudan Tata Kelola Lingkungan yang Baik Dalam Negara Demokrasi”, Jurnal masyarakat yang menjadi korban kerusakan lingkungan, tidak memiliki suatu mekanisme untuk memaksa kelompok penyebab untuk membayar kerugian. Adanya prinsip ini kepentingan masyarakat dapat terwakili dalam komponen pengambilan keputusan.

Berkaitan dengan kekuatiran terhadap perilaku manusia dalam pemanfaatan dan pengelolaan SDA, di dalam laporan kedua Intergovernmental Panel on Climate Change (IPCC) 1995 dinyatakan tanda-tanda pemanasan efek rumah kaca yang disebabkan manusia serta pemanasan serius diperkirakan akan terjadi abad selanjutnya. ${ }^{5}$

Pada KTT Rio + 20 Tahun 2012 hasil kesepakatan para pemimpin dunia dalam suatu dokumen yang disebut "The Future We Want". Dokumen ini merupakan pengembangan lebih terarah dan lebih rinci tentang kelima prinsip yang dicanangkan pada KTT Rio, dua puluh tahun sebelumnya. Terlihat bahwa tidak mudah untuk mencapai pembangunan berkelanjutan. Oleh karena itu yang dibutuhkan adalah komitmen semua pihak bahwa faktor lingkungan hidup yang seimbang dan yang sehat, menentukan kualitas hidup manusia. Ada banyak aspek yang harus dipenuhi mulai dari pendidikan, kualitas laut yang harus terjaga, kualitas udara, kualitas makanan, keseimbangan ekosistem/SDA, pertambangan yang ramah lingkungan, menurunkan angka kematian ibu dan anak, dan sebagainya. Aspek-aspek tersebut harus dipenuhi dengan adanya kerjasama antar negara dan kerjasama masyarakat dari masing-masing negara.

Kesadaran dan keprihatinan negara-negara sebagaimana makna yang terkandung dalam kelima prinsip di atas, yang telah dijabarkan lebih fokus dan rinci dalam dokument 'The Future We Want' yang dicanangkan pada Konferensi Rio + 20, Tahun 2012, diharuskan untuk diimplementasikan dalam kebijakan pemerintah dalam bentuk regulasi. Indonesia telah beberapa kali menyempurnakan undang-undang yang mengatur lingkungan hidup, yang terakhir adalah UU No. 32 Tahun 2009 tentang PPLH. Undang-Un-

Hukum Lingkungan Indonesia, Vol. 1 No.1, Edisi Januari 2014, Jakarta: Indonesian Center for Environment Law (ICEL), hlm.33. 
dang tentang PPLH harus bersinergi dengan peraturan perundang-undangan sektoral lainnya, karena jika tidak maka tidak akan banyak artinya, karena undang-undang ini merupakan pedoman atau acuan bagi aktivitas atau kegiatan yang dilakukan yang kewenangannya berada di sektor lain. Misalnya undang-undang yang mengatur pemanfaatan SDA pertambangan, kehutanan, pertanian, perikanan, dan lain-lain.

\section{Instrumen Pencegahan Pencemaran dan Ke- rusakan Lingkungan Hidup}

UU No. 32 Tahun 2009 tentang PPLH menyebutkan ada 13 (tigabelas) instrumen untuk mencegah terjadinya pencemaran dan kerusakan lingkungan hidup, yaitu; KLHS (Kajian Lingkungan Hidup Strategis); Tata Ruang; Baku mutu lingkungan hidup; Kriteria baku kerusakan lingkungan hidup; Amdal; UKL-UPL; Perizinan; Instrumen ekonomi lingkungan hidup; Anggaran berbasis lingkungan hidup; Analisis resiko lingkungan hidup; Audit lingkungan hidup; dan Instrumen lain sesuai dengan kebutuhan dan/atau perkembangan ilmu pengetahuan.

Kajian Lingkungan Hidup Strategis, merupakan instrumen pencegahan yang diletakkan di urutan pertama, karena dokumen ini akan menjadi dasar kebijakan, rencana dan/atau program pelaksanaan pembangunan dalam suatu wilayah, dan menjadi pertimbangan utama berkaitan dengan pemberian perizinan dalam pemanfaatan sumberdaya alam, termasuk izin usaha pemanfaatan hutan dan pertambangan. Pentingnya KLHS sehingga undang-undang mewajibkan pemerintah dan pemerintah daerah untuk menyusun dokumen KLHS. Karena melalui kajian yang komprehensip dalam dokumen ini, akan dapat dipastikan apakah prinsip pembangunan berkelanjutan menjadi dasar pertimbangan dan terintegrasi dalam pelaksanaan pembangunan yang berkelanjutan di suatu wilayah. Dokumen KLHS berkaitan erat dengan rencana tata ruang wilayah (RTRW), dimana setiap perencanaan tata ruang wilayah wajib didasarkan pada KLHS karena perencanaan tata ruang wilayah ditetapkan dengan memperhatikan daya dukung dan daya tampung lingkungan hidup, yang pengkajian ilmiahnya dilakukan di dalam dokumen KLHS.
Dokumen KLHS sebagaimana tercantum dalam Pasal 16 UU No.32 Tahun 2009, berisikan kajian tentang: Kapasitas daya dukung dan daya tampung lingkungan hidup untuk pembangunan; Perkiraan dampak dan resiko lingkungan hidup; Kinerja layanan/jasa ekosistem; Efisiensi pemanfaatan SDA; Tingkat kerentanan dan kapasitas adaptasi terhadap perubahan iklim; dan Tingkat ketahanan dan potensi keanekaragaman hayati.

KLHS adalah instrumen yang bersifat self assesment yang harus dilakukan oleh masingmasing instansi atau daerah yang mengeluarkan kebijakan, rencana maupun program. KLHS bermanfaat untuk menjamin bahwa setiap kebijakan, rencana dan/atau program "lebih hijau" dalam artian dapat menghindarkan atau mengurangi dampak negatif terhadap lingkungan hidup. Dalam hal ini, KLHS berarti juga menerapkan prinsip precautionary principles, di mana kebijakan, rencana dan/atau program menjadi garda depan dalam menyaring kegiatan pembangunan yang berpotensi mengakibatkan dampak negatif terhadap lingkungan hidup. KLHS merupakan indikator apakah suatu rencana dan usulan kebijakan dapat ditetapkan menjadi kebijakan dan program pembangunan atau tidak. Pasal 18 UU No. 32 Tahun 2009 menyatakan bahwa KLHS akan diatur lebih lanjut dalam peraturan pemerintah, tetapi sampai saat ini, memasuki tahun kelima UU No.32 Tahun 2009, peraturan pemerintah tersebut belum diterbitkan. Walaupun kementerian negara lingkungan hidup telah mengeluarkan pedoman umum penyusunan KLHS, tetapi pedoman ini masih terlalu normatif, untuk menjadi acuan atau pedoman. Belum memberikan arahan implementatif, sehingga memudahkan pemerintah daerah untuk melaksanakan.

Sementara pemanfaatan SDA termasuk di bidang kehutanan dan pertambangan berjalan dan berkembang terus, begitupun dengan pemberian Izin Usaha Pertambangan dengan longgarnya dikeluarkan oleh pemerintah daerah/kabupaten. Walaupun saat ini telah dibatasi dengan terbitnya surat edaran kementerian ESDM pada tahun 2012, untuk wilayah yang belum memiliki RTRW potensi SDA, tidak diperkenankan untuk mengeluarkan IUP. Pemerintah daerah dapat 
menerbitkan IUP untuk wilayah yang telah memiliki RTRW potensi SDA bidang pertambangan.

Pada dasarnya dokumen KLHS merupakan tindakan preventif untuk tidak terjadinya pencemaran dan/atau kerusakan lingkungan, sebagai dasar pertimbangan pengambilan keputusan berkaitan dengan kebijakan pelaksanaan pembangunan. Walaupun masih ada instrumen pencegahan lainnya, seperti perizinan atau izin lingkungan yang meliputi cakupan Amdal, UKL dan UPL, yang bersifat khusus karena lebih pada pendekatan proyek atau pensyaratan yang berlaku untuk setiap aktivitas. Persyaratan berkaitan dengan perizinan merupakan salah kewenangan yang diberikan oleh UU No. 32 Tahun 2004 kepada pemerintah daerah, yang akan dibahas lebih lanjut dalam tulisan ini.

\section{Izin Lingkungan}

Salah satu instrument pencegahan pencemaran dan kerusakan lingkungan hidup adalah instrument perizinan. Perizinan merupakan bagian dari penataan (compliance) melalui penegakan hukum lingkungan, yang sering disebut dengan pendekatan command and control (CAC - atur dan awasi). Instrumen Peraturan Pemerintah Nomor 27 tahun 2012 tentang Izin Lingkungan, merupakan pelaksanaan dari Pasal 33 dan Pasal 41 UU No. 32 tahun 2009 tentang PPLH. Izin Lingkungan adalah izin yang diberikan kepada setiap orang yang melakukan Usaha dan/atau Kegiatan yang wajib Amdal atau UKL-UPL dalam rangka perlindungan dan pengelolaan lingkungan hidup sebagai prasyarat memperoleh izin Usaha dan/atau Kegiatan. PP 27 Tahun 2012 merupakan pengganti PP 27 Tahun 1999 Tentang Amdal dengan penambahan berbagai pengaturan dan ketentuan perihal izin lingkungan. PP 27 Tahun 2012 mengatur dua instrumen perlindungan dan pengelolaan lingkungan hidup, yaitu: instrumen kajian lingkungan hidup (dalam bentuk Amdal dan UKL-UPL); dan instrumen Izin Lingkungan.

Alasan penggabungan substansi tentang amdal dan izin lingkungan dalam Peraturan Pemerintah ini, menurut kementerian negara $\mathrm{LH}$ dengan pertimbangan bahwa AMDAL/UKL-UPL dan Izin Lingkungan merupakan satu kesatuan. Hal ini perlu dibuktikan dalam pelaksanaannya, sebab aturan yang baik adalah aturan yang dapat diimplementasikan, dan adanya peraturan pemerintah ini terus menerus disosialisasikan terutama pada aparatur pemerintah daerah.

Setiap usaha dan/atau kegiatan yang wajib memiliki Amdal atau UKL-UPL wajib memiliki Izin Lingkungan, yang diterbitkan oleh menteri, gubernur, atau bupati/walikota sesuai dengan kewenangannya. Untuk usaha/kegiatan yang berada di wilayah administrasi kabupaten, maka bupati lah yang mengeluarkan izin lingkungan. Izin lingkungan dapat diterbitkan berdasarkan keputusan tentang kelayakan lingkungan yang ditetapkan oleh komisi penilai Amdal, yang untuk kegiatan yang berada di wilayah kabupaten, diketuai oleh bupati. Bupati lah yang memiliki kewenangan untuk menyatakan kelayakan atau ketidaklayakan lingkungan hidup. Berdasarkan Izin Lingkungan inilah maka bupati dapat menerbitkan Izin Usaha Pertambangan.

Izin Lingkungan diperoleh melalui tahapan kegiatan yang meliputi: penyusunan Amdal dan UKL-UPL; penilaian Amdal dan pemeriksaan UKL-UPL; dan permohonan dan penerbitan Izin Lingkungan. Bupati sebagai kepala daerah yang bertanggungjawab terhadap keberlanjutan sumberdaya alam yang ada di wilayahnya, memiliki 'paket' kewenangan sebagaimana diuraikan di atas, untuk aktivitas usaha pertambangan, yaitu: pertama, sebagai ketua komisi penilai Amdal, berwewenang menetapkan atau memutuskan kelayakan atau ketidaklayakan lingkungan hidup terhadap suatu kegiatan usaha pertambangan yang akan dilakukan di wilayahnya; kedua, menerbitkan Izin Lingkungan atau tidak menerbitkan Izin Lingkungan terhadap rencana kegiatan usaha pertambangan yang akan dilakukan di wilayahnya; dan ketiga, menerbitkan Izin Usaha Pertambangan (IUP Eksplorasi dan IUP Operasi Produksi), sebagai dasar beroperasinya kegiatan usaha pertambangan di wilayahnya.

Tiga point kewenangan bupati sebagai kepala daerah sebagaimana disebutkan di atas, merupakan implementasi dari otonomi daerah yang diberikan oleh undang-undang (UU No.32 Tahun 2004). Di masa pemerintahan orde lama dan orde baru, kewenangan tersebut terpusat pada pemerintah (pemerintah pusat). Melalui 
pelaksanaan otonomi daerah, daerah 'diberdayakan', sehingga 'diharapkan' ada pemerataan pembangunan, pemerataan 'hasil' dari pengelolaan usaha pertambangan dan kehutanan yang berada di wilayah kabupaten. Dengan demikian akan mempercepat tercapainya kesejahteraan masyarakat di wilayahnya.

Tetapi sangat disayangkan maksud dan harapan pemberian 'paket' kewenangan tersebut justru menimbulkan 'malapetaka' lingkungan. Kewenangan tersebut justru menjadi obyek praktek korupsi penguasa di daerah, tidak dirasakan merata oleh rakyat di daerah, yang seharusnya mereka memiliki 'hak' untuk menikmati hasil pembangunan dan kekayaan SDA di wilayahnya, sebagaimana prinsip-prinsip yang dicanangkan dalam konsep pembangunan berkelanjutan sebagaimana diuraikan sebelumnya.

\section{Otonomi Daerah dan IUP}

Pertimbangan utama diterbitkannya undang-undang yang mengatur tentang Otoda (UU No.32 Tahun 2004) adalah bahwa dalam rangka penyelenggaraan pemerintahan daerah sesuai dengan amanat Undang-Undang Dasar Negara Republik Indonesia Tahun 1945, pemerintahan daerah, yang mengatur dan mengurus sendiri urusan pemerintahan menurut asas otonomi dan tugas pembantuan, diarahkan untuk mempercepat terwujudnya kesejahteraan masyarakat melalui peningkatan, pelayanan, pemberdayaan, dan peran serta masyarakat, serta peningkatan daya saing daerah dengan memperhatikan prinsip demokrasi, pemerataan, keadilan, keistimewaan dan kekhususan suatu daerah dalam sistem Negara Kesatuan Republik Indonesia.

Pemberian kewenangan untuk mengatur dan mengurus wilayahnya pada dasarnya untuk mempercepat terwujudnya kesejahteraan masyarakat. Pencapaian kesejahteraan masyarakat menjadi pertimbangan mendasar, pemberian kewenangan yang sangat luas kepada pemerintah daerah dalam menyelenggarakan urusan pemerintahan, yang menjadi kewenangan daerah. Pemerintah daerah diberikan kesempatan untuk

\footnotetext{
Faisal Akbar Nasution, “Kebijakan Perimbangan Keuang-
} an antara Pemerintah Pusat dan Daerah Pasca Reforma- menjalankan otonomi seluas-luasnya untuk mengatur dan mengurus sendiri urusan pemerintahan berdasarkan asas otonomi dan tugas pembantuan. Dalam memanfaatkan sumberdaya alam (SDA), khususnya terhadap daerah-daerah penghasil SDA, pemerintah pusat menerapkan dana perimbangan pusat dan daerah tetapi sering menjadi persoalan karena dalam prakteknya departemen teknis di Jakarta melakukan perhitungan yang berbeda-beda, sehingga terkesan pemerintah pusat belum mampu melakukan koordinasi yang baik dalam mengimplementasikan kebijakan otonomi daerah. ${ }^{6}$

Pelaksanaan pemanfaatan sumberdaya alam dan sumberdaya lainnya menjadi kewenangan pemerintah daerah, termasuk pemberian perizinan dalam pemanfaatan sumber daya alam yang berada di wilayahnya. Pada masa orde lama dan orde baru, semua hal yang berkaitan dengan perizinan pemafaatan SDA merupakan kewenangan pemerintah pusat, dan pada era ini praktek korupsi berkaitan dengan perizinan terjadi luar biasa. Kerusakan lingkunganpun terjadi luar biasa. Saat ini di era yang lebih demokratis pemberian kewenangan pengelolaan dan pemanfaatan SDA kepada daerah seharusnya lebih baik dibanding masa lalu.

Kewenangan di bidang SDA yang diserahkan pemerintah pusat kepada pemerintah daerah yang dinyatakan dalam UU No. 32 Tahun 2004, meliputi: pertama, kewenangan, tanggung jawab, pemanfaatan, pemeliharaan, pengendalian dampak, budidaya, dan pelestarian; kedua, bagi hasil atas pemanfaatan sumberdaya alam; dan ketiga, penyerasian lingkungan dari tata ruang serta rehabilitasi lahan. Ketiga butir tersebut menegaskan tentang kewenangan pemanfaatan SDA sekaligus melekat kewenangan untuk mengendalikan dampak dan melestarikan SDA. Kewenangan pemanfaatan SDA pertambangan kepada daerah sudah sewajarnya dilakukan, dengan demikian daerah dapat menggunakan sebagai sumber pemasukan daerah yang dimanfaatkan bagi kesejahteraan masyarakatnya. Namun demikian hal ini diiringi dengan kewaji-

si”, Jurnal Hukum Ius Quia lustum, Vol.18 N0.3, Edisi Juli 2011, Yogyakarta: FH UlI, hlm. 393. 
ban untuk mengendalikan dampak dan upaya pelestarian, yang terjadi sebagai akibat dari pemanfaatan dan pengelolaan pertambangan di wilayahnya. Oleh karena itu Pasal 72 UU No.32 Tahun 2009 tentang PPLH menyatakan bahwa bupati/walikota wajib melakukan pengawasan ketaatan penanggung jawab usaha dan/atau kegiatan terhadap izin lingkungan. Artinya bahwa saat izin lingkungan sudah diberikan kepada pemohon maka fungsi pengawasan terhadap ketaatan penanggung jawab usaha/kegiatan, sudah harus dilakukan. Dengan demikian setiap aktivitas yang tercantum dalam dokumen Amdal dan UKL-UPL dapat dimonitor pelaksanaannya di lapangan.

Kegiatan pertambangan diatur dalam Undang-undang No 4 Tahun 2009 tentang Pertambangan Mineral dan Batubara (UU Minerba). Untuk lebih merinci pelaksanaan dari Undang-undang ini diturunkan kembali dalam bentuk Peraturan Pemerintah (PP) yang salah satunya adalah PP No 23 Tahun 2010 tentang Pelaksanaan Kegiatan Usaha Pertambangan.

Pemberian Izin Usaha Pertambangan (IUP) batuan berdasarkan PP No 23 Tahun 2010 dilakukan dengan cara permohonan wilayah. Permohonan wilayah maksudnya adalah setiap pihak badan usaha, koperasi atau perseorangan yang ingin memiliki IUP harus menyampaikan permohonan kepada Menteri, gubernur atau bupati walikota sesuai kewenangannya. Pembagian kewenangan Menteri, gubernur dan bupati/walikota adalah: Menteri ESDM, untuk permohonan wilayah yang berada lintas wilayah provinsi atau wilayah laut lebih dari 12 mil dari garis pantai; Gubernur, untuk permohonan wilayah yang berada lintas wilayah kabupaten/kota dalam satu provinsi atau wilayah laut 4 sampai dengan 12 mil; Bupati/walikota, untuk permohonan wilayah yang berada di dalam 1 wilayah kabupaten/kota atau wilayah laut sampai dengan 4 mil. IUP mineral batuan diberikan oleh Menteri ESDM (selanjutnya disebut Menteri), gubernur atau bupati/walikota sesuai dengan kewenangannya berdasarkan permohonan yang diajukan oleh: badan usaha, koperasi, dan perseorangan.

IUP diberikan melalui 2 tahapan yaitu: Pemberian Wilayah Izin Usaha Pertambangan
(WIUP); dan Pemberian Izin Usaha Pertambangan (IUP). Pemberian WIUP batuan meliputi beberapa hal. Pertama, Badan usaha, koperasi atau perseorang-an mengajukan permohonan wilayah untuk mendapatkan WIUP batuan kepada Menteri, gubernur atau bupati/walikota sesuai kewenangannya; kedua, sebelum memberikan WIUP, Menteri harus mendapat rekomendasi dari gubernur dan bupati/walikota dan oleh gubernur harus mendapat rekomendasi dari bupati/walikota; ketiga, permohonan WIUP yang terlebih dahulu telah memenuhi persyaratan koordinat geografis lintang dan bujur sesuai dengan ketentuan sistem informasi geografi yang berlaku secara nasional dan membayar biaya pencadangan wilayah dan pencetakan peta, memperoleh prioritas pertama untuk mendapatkan WIUP; keempat, Menteri, gubernur, atau bupati/walikota dalam paling lama 10 hari kerja setelah diterima permohonan wajib memberikan keputusan menerima atau menolak atas permohonan WIUP; dan kelima, Keputusan menerima disampaikan kepada pemohon WIUP disertai dengan penyerahan peta WIUP berikut batas dan koordinat WIUP. Keputusan menolak harus disampaikan secara tertulis kepada pemohon WIUP disertai dengan alasan penolakan.

Pemberian IUP batuan meliputi beberapa hal. Pertama, IUP terdiri atas: IUP Eksplorasi dan IUP Operasi Produksi; kedua, Persyaratan IUP Eksplorasi dan IUP Operasi Produksi meliputi persyaratan: administratif, teknis, lingkungan dan finansial; dan ketiga, Menteri atau gubernur menyampaikan penerbitan peta WIUP batuan yang diajukan oleh badan usaha, koperasi, atau perseorangan kepada gubernur atau bupati/walikota untuk mendapatkan rekomendasi dalam rangka penerbitan IUP Eksplorasi. Gubernur atau bupati/walikota memberikan rekomendasi paling lama 5 hari kerja sejak diterimanya tanda bukti penyampaian peta WIUP mineral batuan.

Menteri, gubernur, atau bupati/walikota dapat menolak permohonan perpanjangan IUP Operasi Produksi apabila pemegang IUP Operasi Produksi berdasarkan hasil evaluasi tidak menunjukkan kinerja operasi produksi yang baik. Menteri, gubernur, atau bupati/walikota sesuai dengan kewenangannya berhak memberikan 
sanksi administratif' kepada pemegang IUP atas pelanggaran ketentuan dalam undang-undang ini berupa: peringatan tertulis, penghentian sementara sebagian atau seluruh kegiatan eksplorasi atau operasi produksi, atau pencabutan IUP. Berdasarkan Peraturan Pemerintah sebagaimana uraian di atas, fungsi kontrol melalui penerapan sanksi administrative cukup jelas diamanatkan dalam peraturan perundang-undangan, sesuai dengan kewenangan masing-masing menteri, gubernur dan bupati/walikota.

IUP Operasi Produksi adalah izin usaha yang diberikan setelah selesai pelaksanaan IUP Eksplorasi untuk melakukan tahapan kegiatan operasi produksi. IUP Operasi Produksi memuat ketentuan antara lain: lingkungan hidup termasuk reklamasi, dana jaminan reklamasi dan pas-catambang, dan rencana pengembangan dan pemberdayaan masyarakat di sekitar wilayah pertambangan, serta hak dan kewajiban pemegang IUP. Artinya setelah IUP diberikan pengawasan melekat harus terus dilakukan oleh pemda sebagaimana ketentuan yang termaktub di dalamnya.

Paket kewenangan memanfaatkan dan mengendalikan inilah yang dalam banyak kasus kerusakan lingkungan, oleh aparat pemda 'sengaja' atau tidak disengaja (karena kekurangmampuan) memaknai sebagai dua bagian yang terpisah, yang seharusnya sebagai suatu kesatuan yang tercermin dalam pengambilan keputusan pemberian IUP. Penilaian layak dan tidak layaknya lingkungan apabila suatu aktivitas pertambangan berlangsung, merupakan persyaratan yang harus mendapat penilaian dari pemerintah daerah dimana rencana aktivitas akan dilakukan. Kemampuan memahami dan kesungguhan hati aparat pemda terutama bupati sebagai pejabat yang memutuskan, memiliki peran strategis.

Sumberdaya alam perlu dikelola dan dimanfaatkan dengan baik dan bertanggung jawab, pemanfaatan dengan mempertimbangkan prinsip kelestariannya, sehingga sumberdaya alam tersebut terus berfungsi bagi umat manusia. Bagaimana agar hal tersebut dapat dilaksanakan? Diperlukan aturan atau hukum untuk mengatur dan memberikan pedoman bagaimana orang harus berperilaku dalam memanfaatkan sumberdaya alam. Menurut Hoebel hukum bereksistensi supaya dapat mengendalikan perilaku, sehingga perbedaan berbagai kepentingan tidak menjadi konflik terbuka.

Begitu banyaknya masalah yang terkait dengan lingkungan hidup yang berkaitan dengan pembangunan khususnya dalam pemanfaatan SDA pertambangan. Di era otonomi ini tampak bahwa ada kecenderungan permasalahan lingkungan hidup semakin bertambah kompleks, yang seharusnya lebih baik dibanding saat belum diberikan kewenangan yang luas melalui penerapan otonomi daerah. Ada sementara dugaan bahwa kemerosotan lingkungan hidup tekait dengan pelaksanaan otonomi daerah, di mana daerah ingin meningkatkan PAD dengan melakukan eksploitasi sumberdaya alam yang kurang memperhatikan aspek lingkungan hidup dengan semestinya. Peraturan perundangan yang berkaitan dengan pengelo-laan lingkungan hidup sudah cukup memadai, namun demikian didalam pelaksanaannya, termasuk dalam pengawasan, pelaksanaannya perlu mendapatkan perhatian yang sungguh-sungguh.

Izin-izin pertambangan yang telah dikeluarkan oleh daerah dalam kebijakan otonomi daerah, semuanya kembali kepada kebijaksanaan kepala daerah. Sebelum izin pertambangan dikeluarkan, "seharusnya" pemda memiliki kemampuan perangkat untuk memverifikasi kemampuan investor, kemampuan SDM dalam konteks pertambangan, ironisnya, itu semua tidak dimiliki oleh pemda secara baik,sehingga timbul pertanyaan, apakah izin yang dikeluarkan itu sudah memenuhi persyaratan, yakni mendorong pertumbuhan ekonomi bagi daerah yang bersangkutan atau tidak?

Pemerintah daerah dalam mengeluarkan IUP, kurang, atau bahkan tidak memperhatikan aspek kaidah-kaidah ilmiah teknis sebuah IUP dikeluarkan, mengabaikan konsep AMDAL atau UKL/UPL atau reklamasi integral antara satu blok IUP dengan IUP lainnya, atau lebih jauh lagi, ditemukan kasus tidak adanya koordinasi konsep pengendalian lingkungan integral atas dua atau beberapa IUP yang secara koordinat kebetulan berada pada batas wilayah administrative pemerintahan satu dengan lainnya, dan 
kelemahan pengawasan dan control adalah salah satu penyebab kerusakan terjadinya keru-sakan lingkungan pasca tambang.

Oleh karena itu terjadinya kerusakan lingkungan akibat aktivitas pertambangan dan kehutanan, yang harus bertanggung jawab ada-lah pemerintah daerah melalui bupati, jika secara administrasi berada di wilayahnya. Pada umumnya SDA pertambangan berada di wilayah kabupaten. Undang-undang memberikan peluang kontrol kepada masyarakat untuk mengajukan gugatan atas 'kecerobohan' administrasi yang mengakibatkan terjadinya kerusakan lingkungan.

Salah satu prinsip dalam sustainable development adalah 'keadilan', keadilan bahwa SDA harus dapat dinikmati oleh semua generasi kini dan yang akan datang, oleh semua orang, tidak hanya sekelompok orang. Karena SDA adalah 'pemberian' Tuhan yang Maha Kuasa yang diperuntukan dan dinikmati umat manusia. Upaya pengelolaan dan pelestarian lingkungan hidup (konservasi sumberdaya alam) merupakan urusan wajib yang menjadi wewenang daerah, baik provinsi maupun kabupaten/kota. ${ }^{7} \mathrm{Hal}$ tersebut juga ditegaskan dalam UU Nomor 32/2009 dinyatakan bahwa setiap penyusunan peraturan perundang-undangan pada tingkat nasional dan daerah wajib memperhatikan perlindungan fungsi lingkungan hidup dan prinsip perlindungan dan pengelolaan lingkungan hidup. Rendahnya pemahaman hukum lingkungan dan kesadaran akan pentingnya pengelolaan sumberdaya alam dan disertai lemahnya penegakan hukum, membawah dampak buruk bagi upaya pembangunan sumberdaya alam dan terjadinya kerusakan lingkungan hidup. ${ }^{8}$ Perizinan merupakan instrument hukum lingkungan yang mempunyai fungsi preventif, mencegah terjadinya pencemaran dan kerusakan lingkungan, dan hal ini berada dalam wilayah hukum administrasi. Penggunaan hukum administrasi dalam penegakan hukum

\footnotetext{
Mustofa, "Dana Bagi Hasil dan Konservasi Sumberdaya Alam di Indonesia Periode Desentralisasi", Jurnal Ekonomi \& Pendidikan, Volume 7 Nomor 2, Edisi November 2010, Yogyakarta: FE UNY, hlm. 128.

$8 \quad$ Fahmi Al Amruzi, "Upaya Penegakan Hukum Lingkungan Melalui Penerapan Asas Strict Liabilty”, Jurnal Masalah-
}

Dewan Perwakilan Rakyat Daerah (yang selanjutnya disingkat DPRD) merupakan perangkat pemerintah daerah yang seharusnya menjalankan fungsinya di bidang pengawasan. Melakukan pengawasan terhadap kinerja pemerintah daerah, termasuk dalam pengelolaan sumberdaya alam di wilayahnya. Tetapi dalam praktiknya, menguatnya lembaga DPRD yang berlangsung bersamaan dengan penataan dan pembenahan kelembagaan daerah, tidak diikuti dengan semangat (moral) dan mental reformasi. ${ }^{9}$

\section{Peran Serta Masyarakat}

Undang-Undang Nomor 32 Tahun 2009 tentang Perlindungan dan Pengelolaan Ling-kungan Hidup (UUPPLH) telah mengatur dan memberikan ruang yang luas bagi masyarakat untuk dapat berperan serta dalam perlindungan dan pengelolaan lingkungan hidup (PPLH). Melalui asasasas partisipatif yang menjadi salah satu asas dalam UUPLH ini, setiap anggota masyarakat didorong untuk berperan aktif dalam proses pengambilan keputusan dan pelaksanaan perlindungan dan pengelolaan lingkungan hidup baik secara langsung maupun tidak langsung.

Selanjutnya dalam proses izin lingkungan yang diatur dalam Peraturan Pemerintah Nomor 27 Tahun 2012 tentang Izin Lingkungan yang mengintegrasikan proses permohonan dan penerbitan izin lingkungan dalam proses Amdal dan UKLUPL. Produk akhir dari proses Amdal atau UKLUPL adalah izin lingkungan. Pasal 9 ayat (6) PP 27 Tahun 2012 dan penjabaran lebih lanjut dari Pasal 44 sampai dengan Pasal 46 dan Pasal 49 PP 27 Tahun 2012 yang mengatur tentang permohonan dan penerbitan izin lingkungan, masyarakat dilibatkan melalui pengumuman dan konsultasi publik.

Dokumen Analisis Mengenai Dampak Lingkungan Hidup (Amdal), sesuai dengan ketentuan dalam Pasal 26 Undang-Undang Nomor 32 Tahun

Masalah Hukum Jilid 40 No.4 Edisi Oktober 2011, Semarang: Fakultas Hukum Universitas Diponegoro, hlm. 455. Kemas Arsyad Somad, “Kedudukan DPRD Dalam Pemerintah Daerah di Indonesia Pasca Perubahan UUD 1945”, Jurnal Masalah-Masalah Hukum, Jilid 40 N0.4, Edisi Oktober 2011, Semarang: Fakultas Hukum Universitas Diponegoro, hlm. 480. 
2009 tentang Perlindungan dan Pengelolaan Lingkungan Hidup (UU 32 Tahun 2009) disusun dengan melibatkan masyarakat melalui pengumuman dan konsultasi publik, sebagai berikut. Pertama, pengikutsertaan dalam penyusunan dokumen amdal melalui proses pengumuman, penyampaian saran, pendapat dan tanggapan masyarakat dan konsultasi publik serta pengikutsertaan masyarakat dalam komisi penilai Amdal, bagi rencana usaha dan/atau kegiatan yang wajib memiliki amdal; kedua, proses pengumuman permohonan izin lingkungan, penyampaian saran, pendapat dan tanggapan masyarakat serta pengumuman setelah izin lingkungan diterbitkan, baik untuk rencana usaha dan/atau kegiatan yang wajib memiliki amdal maupun rencana usaha dan/atau kegiatan yang wajib memiliki UKL-UPL. Proses keterlibatan masyarakat dalam Amdal dan izin lingkungan sangat diperlukan antara lain untuk menjamin terlaksananya hak dan kewajiban masyarakat di bidang PPLH, mewu-judkan pelaksanaan proses izin lingkungan yang transparan, efektif, akuntabel dan berkualitas.

Sebagus apa pun proses legislasi dan isi Undang-undang Nomor 4 Tahun 2009 tentang Pertambangan Mineral dan Batubara dan Undang-Undang No.32 Tahun 2009 tentang Perlindungan dan Pengelolaan Lingkungan Hidup, jika ternyata tanah dan kehidupan di daerah tambang justru rusak, proses yang sudah dijalani akan mati tanpa arti. ${ }^{10}$

\section{Penutup}

Simpulan

Sumberdaya alam pertambangan merupakan kategori sumberdaya yang tidak dapat dipulihkan (non-renewble resources), suatu ketika akan habis. Di samping itu SDA pertambangan merupakan kekayaan alam yang potensial secara ekonomi karena menghasilkan sumber pendapatan yang sangat tinggi, untuk meningkatkan kesejahteraan masyarakat dan pemerataan pembangunan di daerah. Tetapi sekaligus sangat potensial terjadinya kerusakan lingkungan dan ke-

10 Andang L.Binawan, “Jalan Terjal Ekokrasi”, Jurnal Hukum Lingkungan Indonesia, Vol.1 No.1, Edisi Januari merosotan kualitas lingkungan yang diakibatkan aktivitas pertambangan. Kemerosotan bahkan kerusakan lingkungan sebagai akibat dari aktivitas tambang, berdampak jangka panjang. Artinya waktu pemulihan ekologis membutuhkan waktu lama.

Adanya otonomi daerah yang memberikan kewenangan kepada pemerintah daerah melalui Bupati sebagai kepala daerah untuk menerbitkan ijin usaha pertambangan, dalam prakteknya menimbulkan banyak masalah kerusakan lingkungan, karena prosedur AMDAL dan Izin Lingkungan sebagai syarat diterbitkannya IUP, tidak dilaksanakan sebagaimana mestinya. Berkaitan dengan keluarnya Izin Usaha Pertambangan, Bupati sebagai kepala daerah memiliki beberapa 'paket' kewenangan. Pertama, sebagai ketua komisi penilai Amdal, berwewenang menetapkan atau memutuskan kelayakan atau ketidaklayakan lingkungan hidup terhadap suatu kegiatan usaha pertambangan yang akan dilakukan di wilayahnya; kedua, menerbitkan Izin Lingkungan atau tidak menerbitkan Izin Lingkungan terhadap rencana kegiatan usaha pertambangan yang akan dilakukan di wilayahnya; dan ketiga, menerbitkan Izin Usaha Pertambangan (IUP Eksplorasi dan IUP Operasi Produksi), sebagai dasar beroperasinya kegiatan usaha pertambangan di wilayahnya.

Tiga Kewenangan tersebut yang ketiganya berada pada Bupati sebagai kepala daerah, membuka peluang praktek korupsi berkaitan dengan penerbitan IUP. Oleh karena itu diperlukan pelaksanaan pengawasan, pemantauan dan penegakan hukum administrasi maupun pidana yang tegas dan konsisten serta tidak diskriminatif. Partisipasi masyarakat dalam proses pembangunan terutama sebagai kontrol sosial perlu terus dihidupkan dan diberdayakan.

\section{Daftar Pustaka}

Al Amruzi, Fahmi. "Upaya Penegakan Hukum Lingkungan Melalui Penerapan Asas Strict Liabilty". Jurnal Masalah-Masalah Hukum Jilid 40 No.4 Edisi Oktober 2011. Semarang: FH Undip;

2014, Jakarta: Indonesian Center for Environmental Law (ICEL), hlm. 15. 
Baskoro, Dwi Bambang. "Perseteruan KPK dengan POLRI Dalam Upaya Pemberantasan Korupsi”. Jurnal Masalah-Masalah Hukum. Jilid 42 N0.3. Edisi Juli 2013. Semarang: FH Undip;

Binawan, Andang L. “Jalan Terjal Ekokrasi”. Jurnal Hukum Lingkungan Indonesia. Vol. 1 No. 1. Edisi Januari 2014. Jakarta: Indonesian Center for Environmental Law (ICEL);

Fauzan, Muhammad Encik. "Fungsi Sosiologis Undang-Undang Dasar negara RI Tahun 1945 dalam Mememnuhi Hak-Hak Masyarakat". Jurnal Masalah-Masalah Hukum. Jilid 42 N0.3, Juli 2013, Semarang: FHUndip;

Hadi, Rifai. 2013. Penyalahgunaan IUP dan Kerusakan Lingkungan. http://www.suara agraria.com;

Muqodas, Busro. "IUP Bermasalah". Hukumonline.com. 10 Pebruari 2014;

Mustofa. "Dana Bagi Hasil dan Konservasi Sumberdaya Alam di Indonesia Periode Desentralisasi". Jurnal Ekonomi \& Pendidikan. Volume 7 Nomor 2, Edisi November 2010. Yogyakarta: FE UNY;

Nasution, Akbar Faisal. "Kebijakan Perimbangan Keuangan antara Pemerintah Pusat dan Daerah Pasca Reformasi". Jurnal Hukum Ius Quia lustum. Vol.18 N0.3. Edisi Juli 2011. Yogyakarta: FH UII;

Sentosa, Achmad Mas. 2014. "Gerakan Pembaharuan Hukum Lingkungan di Indonesia \& Perwujudan Tata Kelola Lingkungan yang Baik Dalam Negara Demokrasi”. Jurnal Hukum Lingkungan Indonesia. Vol. 1 No.1. Edisi Januari 2014. Jakarta: Indonesian Center for Environment Law (ICEL);

Somad, Arsyad Kemas. "Kedudukan DPRD dalam Pemerintah Daerah di Indonesia Pasca Perubahan UUD 1945". Jurnal Masalah-Masalah Hukum. Jilid 40 N0.4. Edisi Oktober 2011. Semarang: FH Undip. 